\title{
TATTOOING IN THE CONTEXT OF "POST-HUMAN" CULTURAL CHALLENGES \\ - AN INVERTED ICONIC TYPOLOGY
}

Gurie GEORGIU*

\begin{abstract}
This study proposes a psycho-spiritual approach on tattooing from a pastoral perspective. The three sub-divisions of reflection are: 1.) The tattooed body is to be understood, discovered and analysed starting from the individual that decodes the general, the assembly; 2.) Pastoral reading of tattooing: a new anthropological freedom ignored ecclesiastically?; 3.) Tattooing in the context of postmodern psychoemotional mutations. The study highlights reality as seen by psychoanthropologist Giacomo Dacquino, as it draws sketches of a psychopastoral reading of an ever-present shiver in the world of youth, which is little analysed. It can easily be set within the post-human trends, as it objectifies the human being through a reductionist approach, getting inspiration from the iconic typology, creative of civilization in the EuroAtlantic area, but handling it in a vulgar and demolishing manner.
\end{abstract}

Keywords: typology, culture of immediacy, obsession for precariousness, imperialism of exteriority, subjective identity.

\section{Introduction}

Tattooing is an increasingly common trend - among young people especially - who opt mainly for permanent tattooing, which is, however, paradoxical in a culture of immediacy, of precariousness, of bystanders, and yet young people want definitive, irreversible imprints. Which is the correct ratio, from the Orthodox viewpoint, between body and identity? Among the main motivations of tattooing is a thirst for

* Bishop of Deva and Hunedoara, PhD, Professor, "1 Decembrie 1918" University of Alba Iulia (Faculty of Theology), Romania. 
décor, even though in the past tattooing was often a public and explicit protest against an external reality. Has it become a purely decorative option or does it still hide a silent cry of helplessness to change the outside world? Is the body changed because one cannot change one's soul or society?

\section{The tattooed body is to be understood, discovered and analysed from the individual that decodes the general, the assembly}

Certain statistics show that $13 \%$ of the western population is tattooed, by this decision demonstrating the attitude to the body that dominates contemporary culture. Usually, young people tattoo on their skin portraits or names of their favourite singers or football players, as well as important events in their lives (the beginning of a love relationship, the breakup of a friendship, the birth of a child etc.), turning their body into a diary. Any form of tattoo is used to send a message to the relational world that surrounds them. If, for example, we admire a statue for its harmony, with a tattoo we must operate backwards: to decode the general, based on the particular offered to our sight. With today's rebellious young people, we ask ourselves about the limits of the operational intervention performed, and of the relationship between the natural body and one's subjective identity ${ }^{1}$.

Any tattoo ${ }^{2}$ is, obviously, a language, a form of communication, which aims to replace the word. Previously, it was the symbol of a bridge with distant civilizations, in which it represented a form of exorcism of evil and death. In the 1970s, in Europe, tattooing represented public divergent expression (to politics, conformity and consumption culture) through the deliberate alteration and mutilation of the body to express pain, disgust and ownership of a new identity. Skin has become a battlefield, a refuge, a property that you own to fully

${ }^{1}$ Francesco OcChETTA, "Il tatuaggio nella cultura contemporanea", in La Civilta' Cattolica, no. 3.968/2014, p. 157.

2 The term tattoo seems to have entered in Europe with explorer James Cook, who uses the English word tattoo in one of his diaries to reproduce the imitative sound tau-tau, produced by the instrument used to insert the needle into the skin. Its French equivalent is tatouage. The European explorers after 1600 introduced the term in Europe from far Asia (especially from Japan, Tibet, India and New Zealand). 
express yourself freely. This is one of significances/social dimensions of tattooing: it is a radical protest against the world.

Life is given to us to live with enthusiasm, and if this does not happen, there is a reason. If it is pegged by relativism, precariousness, insignificance, bad taste and kitsch, if ugliness bursts freely in our lives, if we have no lofty and inspiring ideals, we are moving in the wrong direction. We then end up no longer living, but struggling helplessly in a dramatic world in which the air becomes un-breathable and anxiety becomes paralyzing. Instead of providing calm and safety, society injects individuals with anxiety and vulnerability. Instead of providing a climate of serenity and relaxation, it maddens, proclaiming that the only human needs are those of an economic nature.

In the postmodern context, it seems that this first function of the tattoo has fainted, the decorative aesthetic preoccupation becoming of prime concern, so as to escape from a normality perceived as dull and monotonous. Another representative of this vision is the body modification movement of the early 1990s, which used to promote body change so as to stir repulsion in those with whom one came into contact. Thus, the individual sphere used to intersect with the public one in order to abuse it. Subsequently, becoming a fashion, many opted for tattoos just because others do it, thus becoming a sign of mediocrity: many adopt acceptable transgressions to prove that they are trendy, although by doing this they demonstrate that they are unable to go beyond the frontiers of mediocrity. When you project private events in the public space, you prove that, to you, non- or even anti-community subjectivity ${ }^{3}$ prevails, and that you are quite insensitive to the requirements of discretion that define authentic refinement.

\section{Pastoral reading of tattooing: a new anthropological freedom ignored ecclesiastically?}

The Scripture speaks about tattooing and it is prohibited in Leviticus: "You are not to make incisions in your flesh on account of the dead nor submit to cuts or tattoos. I am the Lord" (Leviticus 19, 28).

${ }^{3}$ Every drawing has a meaning: circles - the desire to escape; sailor - exorcising the fear of death; snake, panther, lion - transgression and fear. There are also groups that use tattoos as a mark of their own social identity. 
For biblical anthropology, the body is a gift from God that must be protected and preserved. Even in ancient Greece and the Roman Empire tattooing was tolerated but not accepted or promoted. In Judeo-Christian and Greco-Roman culture only those who sinned were marked, visibly, starting with Cain. Fleeing slaves were marked in the same manner. In other cultures (Egypt, Persia, New Zealand), tattooing had social connotations, the body bearing the mark of the social status to which it belonged. Among the Japanese, tattooing was born in the third century, as a distinctive mark of the poorest social classes. In the West, throughout history, tattooing was specific to the lower classes (sailors, prostitutes, prisoners etc.).

Does tattoo revitalization in today's practice demonstrate a new anthropological freedom, which blends private and social life? What consequences at the level of society will tattoos as an established custom have? It is certain that tattooing questions the relationship between inside and outside, between aesthetics and inner self representation. Tattooing is for the youth a form of struggle to go beyond allowed conventionalism, to experience strong emotions; as if life in this contemporary society is no longer satisfactory, no longer sufficient to complete man spiritually.

Many tattooists self-proclaim themselves artists and, perhaps, they are, but on account of the beneficiary subjects who decide to become objects for decoration, like a wall or a handmade creation. Time, ecclesial action, education will be able to help young people realize that the true construction of personal and social identity should not be limited to partial meanings, focused only on a body reduced to the state of an object. Over many centuries, the tattoo has been seen as the mark of a body reduced to an object, instrumentalized, as a desperate cry for freedom in an oppressive disqualifying context.

\section{Tattooing in the context of current psycho-affective mutations. Reading highlights of reality as seen by psycho-anthropologist Giacomo Dacquino}

Contemporary society knows deep mutations, it changes very quickly, often requiring immediate solutions; in the last century, it has seen an acceleration much greater than in all previous centuries 
combined. Therefore, people experience fatigue and feelings of insecurity, which are consequences of social erosion, of continuous strain to adapt to emotional, ethical and social challenges. In addition, the speed of change in technological processes creates a fracture between the ability to absorb innovations and novelties and the requisition to adapt to new continuous changes, which makes it difficult for every one of us to maintain a serene attitude. The right to serenity is perhaps the most ignored right of the human being today. The option of tattooing of many young people aligns in these parameters.

Man has been on the moon and sends space probes and satellites into the universe, but is very insensitive to the sufferings of their peers on Earth. Man only seems to have won simplicity, as a value of daily existence, but in fact, the objectives pursued are increasingly complex and difficult: from the proper education of young people to the emotional stability of the couple, from family unity to capacity for dialogue. There is too much information and too little liaison on Earth! We live very little with the others and very much against the others ${ }^{4}$. By tattooing the young attract attention to them, signal that they exist and that they want to be perceived as such.

We live in a historical period in which people are very concerned about their own portraits, about how others see them: the image receives absolute centrality, conditioning and dictating the behaviour of many ${ }^{5}$.

4 Aggressiveness increases geometrically, correlatively with the loss of values that constellated our parents' existence and that of previous generations. The higher living standards are and the more convenient daily life becomes the more confusion, depression and unhappiness spread. Solitude is the most common disease. Statistics show that every one in three people over 60 lives alone forced by circumstances, not by deliberate choice. Giacomo DACQUINO, Relazioni difficili. Trovare la via della serenita' nell amore, nella sessualita', in famiglia, sul lavoro, Milan, Arnoldo Mondadori Editore, 2006, p. 149.

${ }^{5}$ On the other hand, half the world population is starving, is at the edge of survival, while the other half is becoming obese. Rich countries tolerate or even perpetuate the misery of poor countries, rather than eliminate it. Genuine altruism still exists, but it is discreet, hidden, camouflaged, silent. Good people are not few, but they are very discreet. They do not make noise; you must have very fine ears to hear the good broadcast by the media, you must be particularly careful if you want to identify the good that makes no noise. Around us there are thousands of cases and episodes that testify the courage and kindness of many people, not much is said about them, because the good is not spectacular; that is why the media does not favour it. The 
For example, many participate in TV shows in which they expose, in an exhibitionist manner, their own lives, turning it into a reality show. They expose everything on the surface, but have little ability and willingness to look inward, to listen to themselves. They ignore the fact that exteriority can ruin interiority, that the outside can deplete the inside. Erudite speeches are often delivered, men ostentatiously display their intellectual training and general knowledge, but they demonstrate very low psycho-emotional maturity ${ }^{6}$.

It is not easy to believe in something when there is public continuous crying against errors and horrors. Noise does not encourage reflection. There is a new poverty that affects everyone: poverty of hope! People live with an acute sense of insecurity, so that few trust a bright future. But without hope there are no delightful future projects, one cannot travel with enthusiasm towards the future, we remain locked into a psychological minimalism specific to those who face life as an eternal present ${ }^{7}$. Tattooing is a form of the irruption from the present into a future that bears the seal of the complete.

The civilization of immediacy annihilates long-term life projects, giving way to inner dissatisfaction. The news contains mostly violent events, assaults, rapes, all this injecting, collectively, a state of daily uncertainty. There is more and more talk, but people are very slow in terms of the opposite, in terms of what we can call positive feelings. The

three "S" (sex, sanguine fluid and scandal) seem to increase the audience so they aggressively occupy the public stage.

6 You can find more wisdom with an old semi-illiterate man living in the mountains than in some claptrap speeches claiming to be "high level". Therefore, we need people and examples generating common sense, good taste in society, to help recover publicly honesty, respect, solidarity, to train new generations towards balance, measure, style, true inner beauty. It is so important for the virtue of hope to be protected, promoted and proclaimed in an age marked by confusion. Ibidem.

${ }^{7}$ In recent decades, the sense of the sacred has slowly been lost from the public space, under the erosion of superficial and arrogant secularism. In the hedonistic culture dominated by laxity rules are considered restrictions of human potential; as a result, we see behaviours characterized by the absence of rigor, of inner discipline and seriousness. Economic development is not sufficient without an ethics able to restore the worthiness of emotional experiences; the moral void cannot be compensated through consumerist wealth. Only God can bring us to full inner fulfilment. Ibidem, p. 150 . 
screens have isolated us from our peers; they have oriented us towards fictional non-existent dialogue with the virtual, so that TV sets, mobile phones and computers substitute for the real emotional exchanges of the past. The best screens equipped with "touch-screen" take us easily anywhere, even on the most distant lands, but in no way, do they favour us one thing: meeting ourselves ${ }^{8}$.

Communication is increasingly reduced to noise, without genuine, deep, profound networking, hearts remain cold, minds tickle one another and relationships between people simplify more and more, being reduced to meetings dominated by mistrust and suspicion. Today, many hate for no reason, only for the need to find a scapegoat, an outside culprit to excuse them, to de-guiltify the true culprit, avoiding slipping into depression and missing the invitation to repentance that God sends everyone. Socially, an unfair justice prevails, which is not reassuring?

The future is very unpredictable, and yet many have an excessively pessimistic vision, as if someone could "guarantee" that it will all be bad. The situation can be explained: along with increased consumption hysteria, the collective and individual spiritual void has strengthened, few people remembering the biblical warning: Vanity of vanities; all is vanity! There is a great poverty of values in the world,

${ }^{8}$ Things, material possessions, wealth are outside us, and to be happy we need the lifeblood of love, the only one that can oxygenate our inner being; this is the only and true human need and it should also be their supreme interest. For each of us there comes a time when proclaiming the meaning of our own life is essential. After this renewal, it is necessary to develop a new code of behaviour as the old one is no longer valid or relevant. It is of great importance at what age we find this need. Idem, Legami d'amore. Come uscire dall'isolamento affecttivo, Milan, Arnoldo Mondadori Editore, 1997, p. 4.

${ }^{9}$ Slowly, the world becomes a huge shopping centre satisfying a huge appetite for things, goods, but also strong, neurotic emotions. Man, has become a prisoner of an imperialist sense of possession. Man, does not know the meaning of sacrifice, so they cannot recognize its value. And if - in the past - man was trained from an early age to discipline their desires, to control their impulses, to minimize (and reduce) their needs, today the situation is exactly the reverse: man, is invited to seek to satisfy all their desires, all their needs, even improvised, invented ones, spewing from a capricious, immature will. And the fact that, often, option for an objective means automatically giving up on another is ignored. Therefore, we live in a society of $I$ want! I need! I demand! ... These are the slogans that define the turmoil of the individual and their tumultuous and fidgety mental life. Ibidem, p. 5. 
poverty of sense and meaning (in what we do), poverty fueled by the populist approaches of the media and by the technological developments which are a lot faster than the pace of the inner psycho-affective progress. Thus, we came to live in a civilization where things matter more than individuals, wealth more than men, in a ubiquitous and allencompassing ethical mess, in which all people are ego-referential, reporting everything to self-interest. We witness a hypertrophic growth of $I$ and Mine against We and Ours ${ }^{10}$.

\section{Conclusions}

Therefore, the individual is left alone in front of multiple complementary needs, hidden behind the questions: Why are we born? What is the mystery behind everyone's coming into the world? Where do we come from? What is the meaning of life? Why should we live? Where do we go when we die? Why is there evil? Why do we have to suffer? All questions of interest to both believers and atheists, both the pious and the less religious, questions to which only religion can respond with responsibility and competence. And, until each finds a response on their own, young people are happy with the proviso, with a portrait provided to others for consumption, essentialised in a tattoo of symbolic dimension.

\section{References}

1. De Bertolis, Ottavio, "Corporeita' e diritto privato", in La Civilta' Cattolica, no. 3.811, p. 31-43.

2. ConRADS-KRONENBERG, Peter, "Iconografia cristiana e pittura rivoluzionaria", in La Civilta' Cattolica, no. 3.707, p. 445-457.

3. DACQUINO, Giacomo, Legami d'amore. Come uscire dall'isolamento affecttivo, Milano, Arnoldo Mondadori Editore, 1997.

4. DACQUINO, Giacomo, Relazioni difficili. Trovare la via della serenita'

10 Hedonistic consumerism pushes us to acquire more and more, in an obsessivecompulsive manner, because not enough love is received - from anywhere! Emotional drought is caused by the subtle repudiation of the Church from the public space. It imposes itself in a society lacking a consistent ethical culture and it is fuelled by media pressure. In addition, $I$ and Mine are anti-spiritual realities, toxic to the spirituality which is the engine of good in a society. These two concepts, $I$ and Mine, make people superficial and unscrupulous, and spiritual darkness once installed, the conditions for affective and emotional loneliness have been created. 
nell amore, nella sessualita', in famiglia, sul lavoro, Milan, Arnoldo Mondadori Editore, 2006.

5. MuCCI, Giandomenicco, "Il difficile rapporto tra i giovani e la fede", in La Civilta' Cattolica, no. 3.851, p. 484-489.

6. OCCHETTA, Francesco, "Il tatuaggio nella cultura contemporanea", in La Civilta' Cattolica, no. 3.968, p. 157-165.

7. OcChetTA, Francesco / BenANTI, Paolo, "La politica di fronte alle sfide del postumano", in La Civilta' Cattolica, no. 3.954, p. 572-584.

8. POUPARD, Paul, "Teologia della evangelizzazione delle culture", in $I l$ Regno Documenti, 5/1986.

9. SALE, Giovanni, "L'Isis e la tattica della spettacolarizzazione della violenza", in La Civilta' Cattolica, no. 3953, p. 430-439.

10. WeILER, Joseph, Un'Europa Cristiana. Un saggio esplorativo, BUR Biblioteca Univ. Rizzoli, 2003.

11. *** Per una pastorale della cultura, Roma, Citta' del Vaticano, 1999. 